\title{
污染海水によるアルミニウム黄銅復水器管の 腐食におよ葟す諸因子についで
}

佐藤史郎 ${ }^{* *}$

Shiro Sato: Some Factors Affecting the Corrosion of Aluminium Brass Condenser Tubes by Polluted Sea Water. Recently, the power stations situated in large cities of ten encountered with the troubles of severe corrosion of condenser tubes of aluminium brass by polluted cooling water. This paper reports the results of experiments on the individual effect of some factors which are characterizing the polluted water on the corrosion of aluminium brass tubes. The experiments were performed by following two method; (1) the corrosion test on tube specimens in which $3 \% \mathrm{NaCl}$ solution containing hydrogen sulfide or ammonium ion is circulated through the tubes (2) the corrosion test on sheet specimens using rotating disc corrosion testing apparatus in $3 \% \mathrm{NaCl}$ solution of various $\mathrm{pH}$ containing hydrogen sulfide and in polluted brackish water in which the $\mathrm{pH}$ is controlled to be kept in weak alkaline value. Results obtained were as follows ; (1) Hydrogen sulfide in order of $1 \mathrm{ppm}$ is very active to the corrosion in neutral solution, causing the pitting, but is less active in alkaline solution. (2) Action of ammonium ion in order of $10 \mathrm{ppm}$ or more is also effective to cause pitting, but is not so prominent as that of hydrogen sulfide. (3) Decreasing of $\mathrm{pH}$ value from that of clean sea water to that of polluted water with increasing degree of pollution promotes the corrosion without the action of sulfide. (4) Controlling of $\mathrm{pH}$ of polluted water in weak alkaline value is effective to inhibit the corrosion but in practice the difficulty by depositing of insoluble calcium carbonate in tubes which will impede the performance of condenser tubes is expected.

(Received September 30, 1963)

** 住友軽金属工業株式会社研究部 (Research Laboratory of the Sumitomo Light Metal Industry
Ltd., Nagoya)

* 1963 年 4 月本会東京大会に発表 


\section{I. 緒}

アルミニウム黄銅が復水器管として使用されるよ5にな つてから，30 年以上を経過しているが，その間の使用実績 によれば，清浄な海水を冷却水に使用している限り，復水 器管の腐食の問題は恬とんぞ見られなくなつていた。

しかし，近年になりて，都市周辺の港垐や河口の海水， または河海水の污染か激しくなつてきたのと並行して，活 染した海水亲たは河海水を冷却水に使用している火力発電 所の復水器管には極めて苟烈な腐食が発生するようになつ た。この腐食はるが国の及ならず，英米両国に括いて子等 しく発生しているすののようである(1)(2).

污染海水による腐食をうけたアルミニウム黄鈵復水器管 の䍿查結果によれば，各管飞共通する特徵としてつぎのよ らなことが見受けられている(3)。(1) 腐食は孔食状のもの を主とし，孔食の進行速度は $0.2 \sim 0.5 \mathrm{~mm} / \mathrm{yr}$ 達する。 (2) スライム状のスケールが厚く管太面を覆っている. (3) スケールは銅，奇機物を多量に含み，イオウを0.3〜 10\%

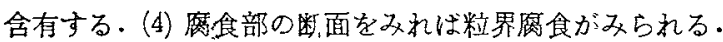
しかし，各事例の詳細な状況は互に大きく買なつている点 る多く，污染海水炕よる简食の要因が画一的なものてはな いことを示しているよ5にる思它る。

污染海水腐食を生ぜしめた海水の分析結果によれば(3) (5)，共通する特徵として，(1) $\mathrm{pH}$ が清清海水上りも低い こと( $\mathrm{pH}: 6.8 \sim 7.5) ，(2)$ アンモニウムイオンが含まれて いること $(1 \sim 30 \mathrm{ppm}) ，(3)$ 溶存酸素が少ないこと。(0〜4 $\mathrm{ppm}) ，(4)$ 有機物質が多く含有されていることなどがあ りイオウイオンとその化合物(いる体る硫化物) は常に検 出されているとは限らず，溃所括よひ時期により検出され たり，検出されなかったりしている、ただし，冷却水の取 入れ口の河底や海底の堆積物の中には多くの場合かなり多 量のイオウ分が検出されている.

イオウを含む化合物の腐食作用につき，Rogers(6) 快蛋白 質の腐敗および分解過程で生ずる有機イオウ化合物（たと えばシスチン）の復極剤としての作用を明らかとしている が，その作用は硫化水素などのい的る硫化物の作用比比 較すればかなり小さい上らである。Evans(7) 蛘細なデー タを示していないが，苛烈な腐食が硫化水素を含む海水に よつて生ずることを述へており，このことは池村，中村。

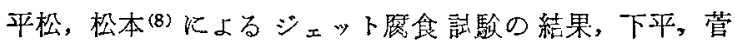
原，佐藤 ${ }^{(9)}$ による分检泪定の結果，Tcdhunter ${ }^{(2)}$ とよる

(1) P. T. Gilbert: Chemistry and Industry, (1959), July 11.

(2) H.A.Todhunter: Power, 100 (1956), March 85.

（3）大と点代，大津，佐滕：住友軽金原技報， $1(1960)$, 260 ; 同 $2(1961), 127$.

（4）清浦: 化学之工業, 11 (1958),977.

（5）田中：住友俥金属技報，3(1962)，225；242.

(6) T.H.Rogers: J.Inst.Metals, 75 (1948 49), 19 .

(7) U.R.Evans: Corrosion and Oxydaticn of Metals, (1960), 478 .

（8）池村, 中村, 平松, 松本: 防食技術, 10 (1C61)，203.

（9）下平，菅原，佐藤：住友軽金属技報，4(1963)，31.
実例の検款結果なならびに著者が経験した硫化水菜を含む 海水による異常腐食の発生例(10)などからも肯定しうるこ とである。しかし，腐食，とくにいかゆる硫化物による腐 食を考光た場合 $\mathrm{pH}$ の変動は符食汇対して当然支配的な影 響を有しているとみられるが，この点については汪とんど 検討がなされて䗆らず，また污染海水中には常に検出され るアンモニウムイオンの歷食に対する作用についてる十分 なデータをみない。

以上の上うな情枩から，著者は污染海水汇上るアルミニ ウム黄銅復水器管の腐食反応に扎いて，主要な因子をなし

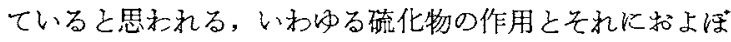
す $\mathrm{pH}$ の变動の影響を諝査した。同時に腐食に和よぼすフ ンモニウムイオンの作用も検討した。そして，これらの因 子がいずれも污染海水によるフルミニウム黄銅復水器管の 腐食の主要因子を構成しているるのと考えられることを明 らかとした。

な怙，本研究の結果， $\mathrm{fH}$ を微アルカリ性に保っことに より硫化物による窝食をかなり抑制しうる可能性のるるこ とがわからたので，污染河海水を用いて実験し，一防食法 としての実用珄についてる検討した。

\section{II. 通 水腐食 試 験}

\section{1. 実験方法}

外径 $25.0 \mathrm{~mm}$, 肉厚 $1.0 \mathrm{~mm}$ または外径 $19.0 \mathrm{~mm}$, 肉 厚 $1.0 \mathrm{~mm}$ の復水器㕅継目無黄㼬管 2 種 (JIS H-3632. Bs TF-2. 通称アルブラック管) 颙質材を試料に用い，管の 内面に流速 $2 \mathrm{~mm} / \mathrm{sec}$ て腐食媒としてつぎの溶液を 740 時 間通した. (1) $[3 \% \mathrm{NaCl}$ 溶液, $\mathrm{pH}: 6.8 \sim 7.0 ，(2)$ 硫化 水素 $1 \mathrm{ppm}$ を含む $3 \% \mathrm{NaCl}$ 溶液, $\mathrm{pH}: 6.8 \sim 7.0,(3)$ 工 ンモニウムイオンを 13 特よび $80 \mathrm{ppm}$ 含む $3 \% \mathrm{NaCl}$ 溶 液, $\mathrm{pH}: 7.3$.

上記 (2)の溶液の坛験飞和いて, 硫化水素は試験中に消 耗する傾向に出つたので，滥耗する量 $(0.01 \mathrm{ppm} / \mathrm{min})$ 飞 見合亏量の硫化水素を涉厚液 $\left(\mathrm{H}_{2} \mathrm{~S}: 1,000 \mathrm{ppm}\right)$ の滴下に より常時補給した。上記 (3)[の落液のアンモニウムイオン 恬 $\mathrm{NH}_{4} \mathrm{Cl}$ として加えた。溶液中の硫化水素怙よびアンモ ニウムオンの濃度は工業用水分析方法 (JIS K-0101-1960) によつて確めながら試験を叔こなつた。

\section{2. 実験結果}

(1) $3 \% \mathrm{NaCl}$ 溶液による通水腐食試験結果 汪とんと腐食が生じなかった。

\section{（2）硫化水素 $1 \mathrm{ppm}$ 索む $3 \% \mathrm{NaCl}$ 溶液 による通水腐食試験結果}

同一条件のテストが 2 度怙こなわれたが注とんど同一の 結果が得られた。管はPhoto.1 上にみる上うな付着物を 生じ，その下層には Photo.1中にみるような腐食が生じ ていた。この俩食部を詳細にみれば，小さな孔食が群をな

（10）佐藤：住友軽金属技報，4(1963)，48. 
して全域に分布しで扣り，污染海水による腐食を受げた復 本器管の内面状況と類似の形態を示していたが，その個々 の孔食の大きさは直径 $1 \mathrm{~mm}$ 末満で小さかつた. 孔食部の 断面の状況は Photo.1下のようであり，腐食は結晶粒界に 優先的に生じている傾向がみられた．管内面付着物を分析 したところ Table 1 のよ5であり，約 $1 \%$ の $\mathrm{SO}_{4}{ }^{--}$以外 のSを含むことをはじめとして，污染海水による腐食を受

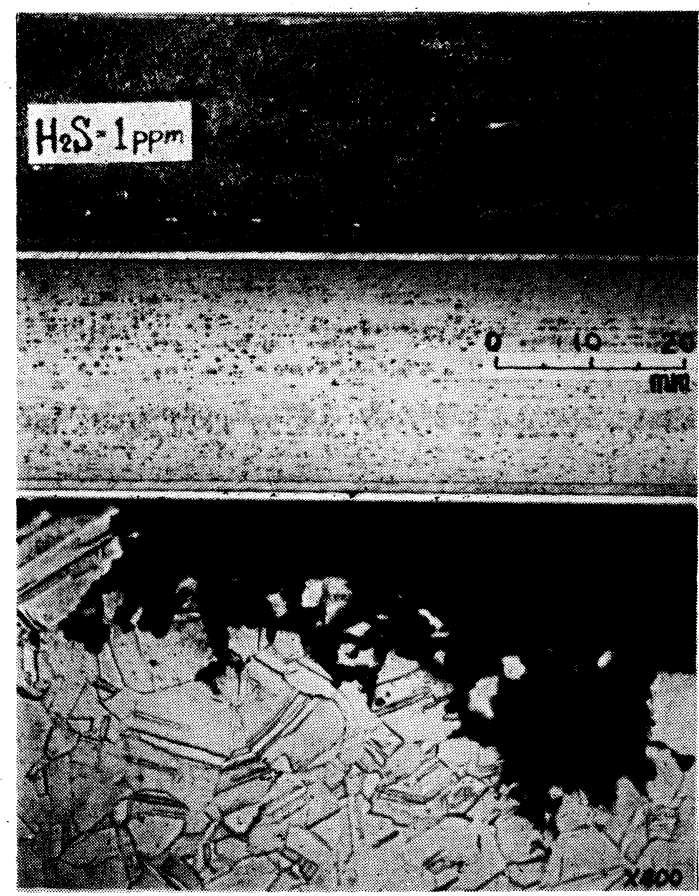

Photo. 1 Altminium brass tube corroded by circulating $3 \% \mathrm{NaCl}$ solution containing $1 \mathrm{ppm}$ of hydrogen sulfide, showing the formation of slimy scale and severe pitting corrosion.

けた復水器管の内面付着物と似たものであつた. 内面付着 物量は $25 \mathrm{mg} / \mathrm{cm}^{2}$ であつた。

Table 1 Chemical analysis of scale formed in the aluminium brass tube corroded by $3 \% \mathrm{NaCl}$ solution containing $1 \mathrm{ppm}$ of hydrogen sulfide. (wt \%)

\begin{tabular}{c|c|c|c|c|c|c}
\hline $\mathrm{Cu}$ & $\mathrm{Zn}$ & $\mathrm{Fe}$ & Total S & $\mathrm{SO}_{4}^{--}$ & $\mathrm{S} *$ & Ignition loss \\
\hline 23.3 & 2.6 & 0.18 & 1.1 & 0.82 & 0.83 & 26.1 \\
\hline
\end{tabular}

\section{(3) アンモニウムイオンを含む $3 \% \mathrm{NaCl}$}

\section{溶液に上る通水腐食試験結果}

管は薄い褐色のスケールに覆われて拈り，ところどころ に緑色の斑点がみられた。緑色の斑点が存在した部分は軽 い孔食を受けていた，孔食はアンモニウムイオンが少ない 溶液 $(13 \mathrm{ppm})$ によつて腐食された管よりも多い溶液 (80 ppm) によつて腐食された管に多く生じていた。管の内面 状況をPhoto.2 亿示す.

以上の通水試験上りつぎのことがわからた。
(1) 硫化物 $\left(\mathrm{H}_{2} \mathrm{~S}\right)$ の存在は污梁海水による復水器管の腐 食の典型例と類似の特徵を有する腐食を生ぜしめ5る。す なわち, 硫化物は污染海水による復水器管の腐食の主要因 子と考党られる.

(2) アンモニウムイオンの存在は孔食を発生させる。 そ の状㳳は污染海水による腐食を受けた復水器管の典型的な 例とはかなり異なつているが，腐食例の中にはよく似てい

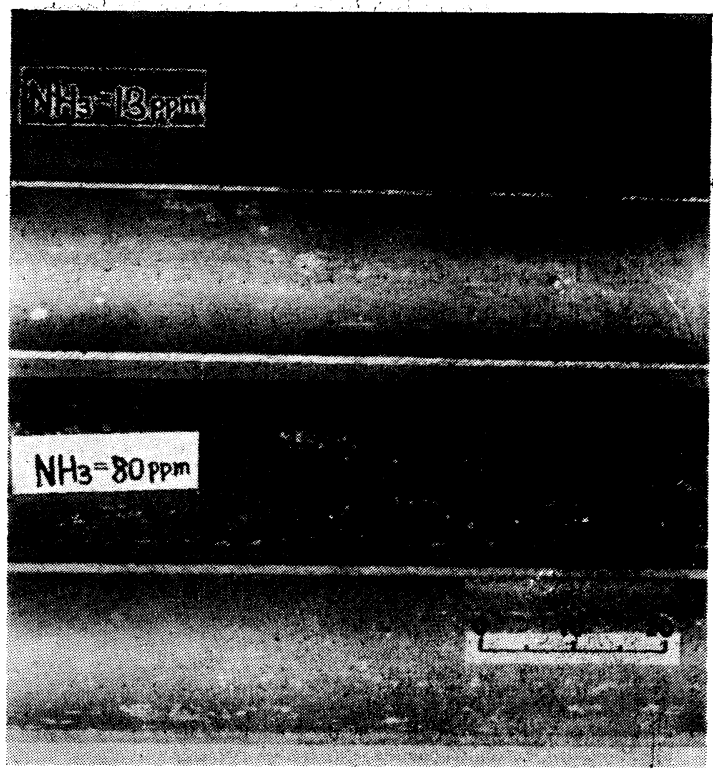

Photo. 2 Aluminium brass tube corroded by circulating $3 \% \mathrm{NaCl}$ solution containing 13 and $80 \mathrm{ppm}$ of ammonium ion, showing the pitting corrosion.

るものもある. したがつてアンモニウムイオンも污染海水 腐食の要因として無視しらるものではない。

\section{III. 回転 腐、食試 験（その 1)}

\section{1. 実験方 法}

2 台の回転式横型腐食試験機（水車式潰食試騟装置とも いわれる(11) を一対にして用い，つぎの各条件で腐食試験 を括こなつた。

(1) 試験片：同一条件で同時に 12 枚のアルミニウム黄 銅板 $(20 \times 50 \times 1.2 \mathrm{~mm})$ を試験片として用いた。

（2）回転速度：試験片の先端の速度が $2.0 \mathrm{~m} /$ / ec になる よ5に回転速度を定めた。

(3) 温度： $40 \pm 2^{\circ} \mathrm{C}$ 江調節した。

(4) 液: $3 \% \mathrm{NaCl}$ 溶液の $\mathrm{pH}$ を $\mathrm{HCl}$ 扰よび $\mathrm{NaOH}$ に より，5.6,6.8,7.5, 8.0, 8.5, 9.0 および 10.0 と調節した. この液を 2 台の腐食試験機内に入れ，一方の試駼機にのみ 硫化水素を $1 \mathrm{ppm}$ になるように加えつつ試験を拍こなつ た.

(5) 時間： 1 回の試験の継続時間は 360 時間とした. た

（11）日本金属学会編：新制金属講座，測定検査篇，化学 冶金测定法, (1958), , 91. 
だし， $\mathrm{pH}$ が 5.6 の場合，腐食が激しく 360 時間の試験を 継綕することができなかつたので 120 時間で試験る中止し た。

\section{2. 実 験 結 果 \\ （1）腐食状況}

同一試験条件で試験した試験片 12 枚の間には大きな差
り，粒界腐食多文らた〈(Photo.4). しかし，硫化物を含 なない $\mathrm{pH}$ が $6.8,7.5$ および 8.0 の液によつて腐食された 試験片にはスケールの付着がなく試験片は平滑であつた. たた，pHが 6.8 の液によつて腐食された試娩片にのみ， 一見して筫食状の，浅い凹み部がみられた。(3) pH 9 特よ び 10 で試験した試験片は硫化物の有無にかかわらず,ほ

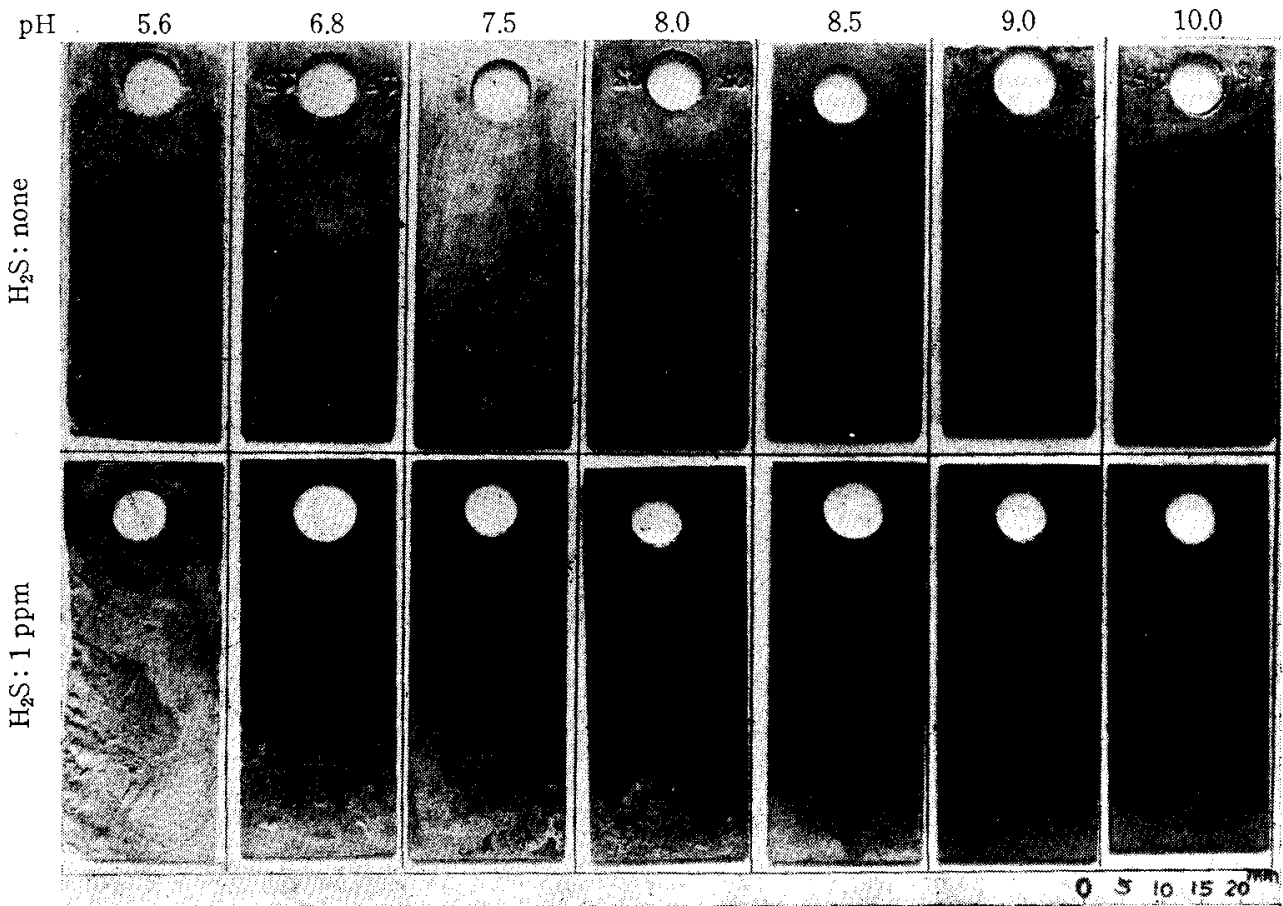

Photo. 3 Corrosion of aluminium brass specimens fixed on the rotating discs and exposed to $3 \% \mathrm{NaCl}$ solution of various $\mathrm{pH}$ value containing $1 \mathrm{ppm}$ or none of hydrogen sulfide. (velocity: $2.0 \mathrm{~m} / \mathrm{sec}$ )

はみられず，バラッキは小さいようであつたが，試験条件 の異なる各試験片の腐食状沿は，試験条件により明暸な差 を示していた，各試験片の腐食状況をPhoto. 3 に示す. Photo.3をもとにつぎのことがい党る. (1) $\mathrm{pH}$ が5.6の 場合, 硫化水素の有無にかかわらず, 試験片は全面的に均 一に腐食され不溶性の付着物はみられなかつた。このこと から，溶解を主とする反㐫が生じたものとみられる。(2) $\mathrm{pH}$ が 6.8,7.5 抗よび 8.0 の硫化物を含も液によつて腐食さ

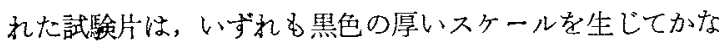
り激しく孔食状に腐食されて拉り，その深さは Table 2

Table 2 Maximum depth of corrosion pits of aluminium brass specimens corroded by $3 \% \mathrm{NaCl}$ solution of $\mathrm{pH} 6.8 \sim 8.0$ containing hydrogen sulfide. $(\mathrm{mm})$

\begin{tabular}{c|c|c|c}
\hline $\mathrm{pH}$ & 6.8 & 7.5 & 8.0 \\
\hline $\begin{array}{c}\text { mean } \\
\text { range }\end{array}$ & 0.25 & 0.23 & 0.08 \\
& $0.10 \sim 0.35$ & $0.10 \sim 0.32$ & $0.06 \sim 0.10$ \\
\hline
\end{tabular}

に示したようであつた。この状召は污篓海水によつて應食 を受けたアルミニゥム黄銅復水器管の状況によく似て和
とんど腐食を生じて和らず，アルカり性では硫化物が含ま れていても硫化物はほとんど腐食に関与しないことがわか つた.

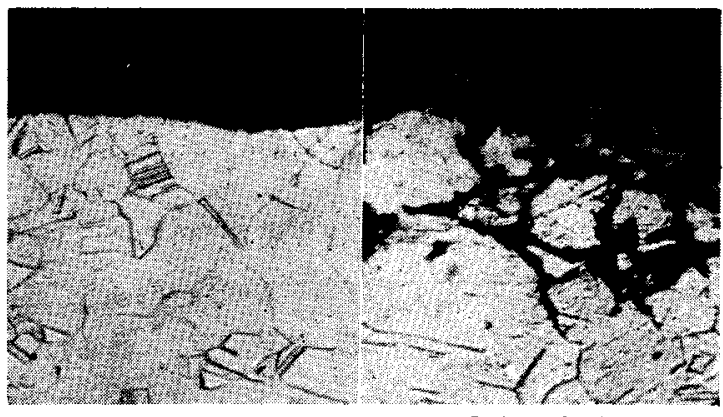

$\mathrm{pH}: 7.5, \mathrm{H}_{2} \mathrm{~S}:$ none

$\mathrm{pH}: 7.5, \mathrm{H}_{2} \mathrm{~S}: 1 \mathrm{ppm}$ $(\times 400)$

Photo. 4 Cross sections of aluminium brass specimens shown in Photo.3.

\section{(2) 重量減少量の測定結果}

各試験片の重量减少量女测定した。同一陚䮦条件下に括 ける各測定值 $(12$ 二)の間のバラッキは概して小さく, 変動 係数は $0.1 \sim 0.2$ 程度であつた. この值 (12コの平均值) か 
ら腐食速度（腐食量より換算， $\mathrm{mm} / \mathrm{yr}$ ) に扣よぼす $\mathrm{pH}$ らびに硫化物の有無の影響を求めた (Fig. 1). Fig.1より

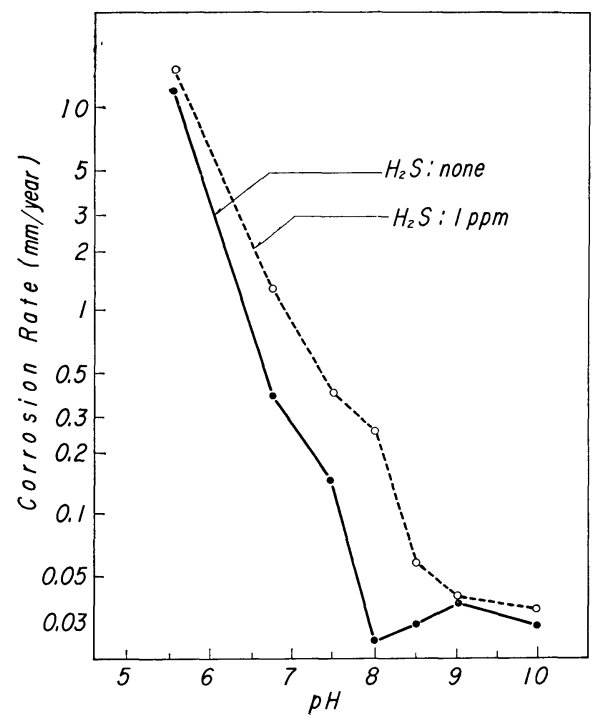

Fig.1 Effect of $\mathrm{pH}$ and hydrogen sulfide on the corrosion rate of aluminium brass by $3 \%$ $\mathrm{NaCl}$ solution. (velocity: $2.0 \mathrm{~m} / \mathrm{sec}$ )

つぎのことがいえる. (1) 硫化物が存在しない場合, $\mathrm{pH}$ が 8 より減少すれば腐食速度はそれにつれて単調に増大 する. その割合は水素イオン濃度とほ济比例的な関係浮あ る. しかし, $\mathrm{pH}$ が 8 以上に增大しても腐食量はあまり変 化しない。(2) 硫化物が存在する場合, $\mathrm{pH}$ が 9 より減少 すれば水素イオン濃度の増大に比例して腐食速度は增大す る. (3) $1 \mathrm{ppm}$ の硫化水素は $\mathrm{pH}$ が 6.8 8.5 すなわち, 中性から微アルカリ性の範囲にあるとき合金面に黒色の スケールを生ぜしめ, その下層に孔食状の腐食を発生さ せ，腐食速度を著しく増大させる。しかし，酸性またはつ ルカリ性のとき硫化物の影響は顕著でない。

以上の実験の結果から, 污染海水によるアルミニウム黄 銅復水器管の腐食は硫化物の作用を大きく受けているもの であることがわかつたが, 同時に污染海水の $\mathrm{pH}$ が清浄海 水の $\mathrm{pH}$ よりも0.5〜1程度小さいことも腐食に対して著 しい影響を与えているものであることがわかつた。

\section{IV. 回転 腐食試 験（その2）}

前章の実験から, 中性なしい微フルカリ性の硫化水素 $1 \mathrm{ppm}$ を含む $3 \% \mathrm{NaCl}$ 溶液に上り, 污染海水に上る復水 器管の腐食例とほとんど完全に一致する腐食を生ぜしめう ることがわかつた.このような腐食の進行過程を知るため に腐食量と経過時間の関係をつざのような簡単な実験から 求めてみた。

\section{1. 装置および実験方法}

III と同じ回転式横型腐食試験装置を用い, 同様の回転速 度, 温度和よび試験片によつて下記条件で腐食試験をおこ なつた。
(1) 液： $\mathrm{pH} 8$ の $3 \% \mathrm{NaCl}$ 溶液とそれに $1 \mathrm{ppm}$ の $\mathrm{H}_{2} \mathrm{~S}$ を添加したものを用いた。

(2) 試験時間：30，60,120，240 時間毎に各 4 枚の試験片 を取外し，前章に記した 360 時間の試験結果と合せた.

\section{2. 実験結果}

試験時間と腐食量の 関係を Fig. 2 亿示す. 硫化水素が 在存しない場合, 腐食の進行速度は一般によく知られてい るごとく, 抛物線的に減少するものとみられるが, 硫化水 素が存在した場合, 腐食速度は一度減少してから (30～120 時間）再び増大寸るようになる。この現象はよくいわれて いるごとく，まず均一な被膜が生じてから，その被膜が硫 化物の作用を受けて部分的に䟝離されることによつて生ず るものではないかと思われる。

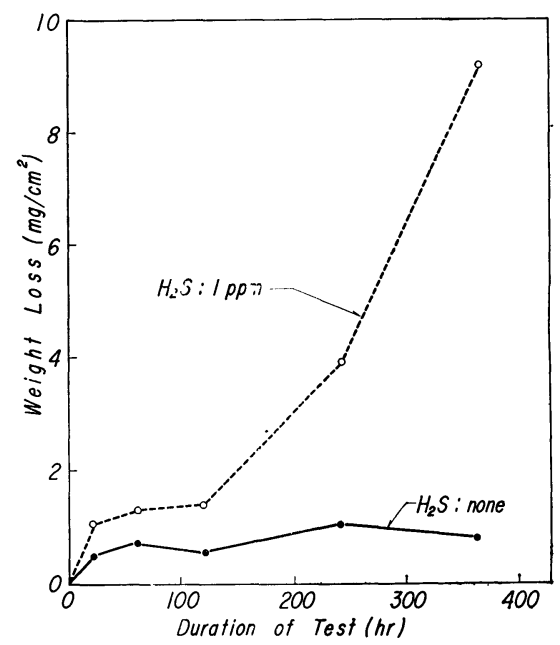

Fig. 2 Variation of corrosion rate of aluminium brass with duration of test in $3 \% \mathrm{NaCl}$ solution containing $1 \mathrm{ppm}$ or none of hydrogen sulfide. ( $\mathrm{pH}: 8.0$, velocity: 2.0 $\mathrm{m} / \mathrm{sec}$ )

\section{V. 考察}

主として通水腐食試験の結果から, いわゆる硫化物の存 在が污染海水腐食の主要な因子であることが確認された が，アンモニウムイオンの作用もそれが孔食を発生させ５ ることから，無視しえないものであることがわかつた，污 染海水の分析結果によれば, 硫化物は常に検出されている とは限らず，場所的拈よび季節的に限られた範囲内でのみ 検出されていることが多い。一方, アンモニゥムイオンは 1 30 ppm の範囲で常時検出されている. したがつて, 污 染海水腐食の主要因子として硫化物とアンモニアのうちい ずれを重視すべきであるかはその分析結果をみて判断すべ きであり，一概に断定しうるものではないと考学られる。 污染海水による復水器管の腐食例をみれば, 全域汇厚い黑 色のスケールを生じ，均等に分布する激しい孔食を多数生 ずる型の腐食例 (いわゆる典型例) とスケールの付着状況 は清浄海水を冷却水とする復水器管の状況と大差がないに 
もかかわらず，限られた部分以の收少数の孔食を有してい る型の腐食例とをみることができる。硫化物とアンモニア

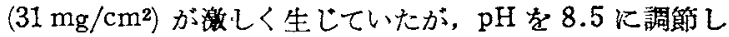
た河海水によつて生じた腐食は極めて僅少 $\left(0.11 \mathrm{mg} / \mathrm{cm}^{2}\right)$

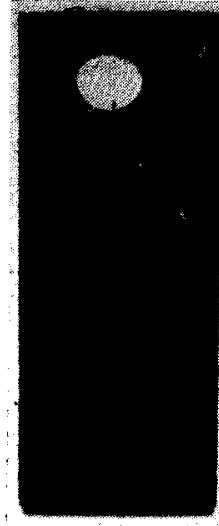

(a)

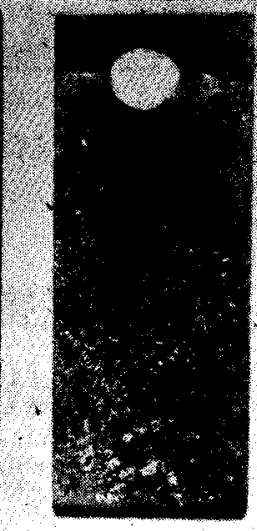

Corrosion by polluted brackish water $(\mathrm{pH}: 7.0 \sim 7.4$, weight loss: $\left.31 \mathrm{mg} / \mathrm{cm}^{2} .360 \mathrm{hr}\right)$

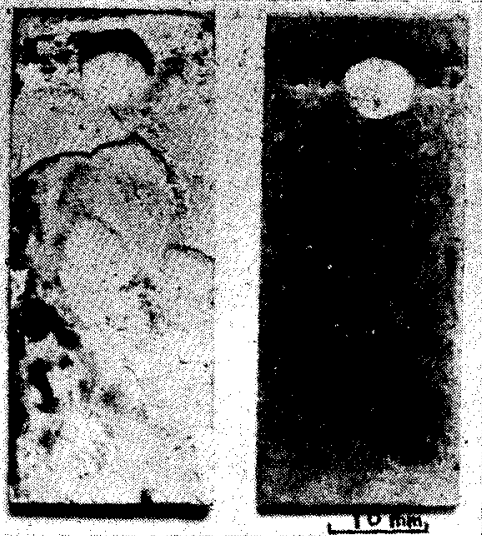

(b) Corrosion by polluted brackish water of controlled $\mathrm{pH}$ value (pH: 8.5 , weight loss: $0.11 \mathrm{mg}$ / $\left.\mathrm{cm}^{2} .360 \mathrm{hr}\right)$

Photo. 5 Effect of $\mathrm{pH}$ control by $\mathrm{NaOH}$ addition on the corrosion of aluminium brass by polluted brackish water. Alternate specimens have had deposits removed.

の窗食特性からみて，前者つ例が流化物を主とするるので

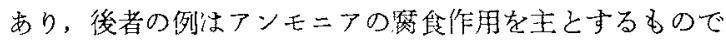

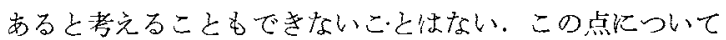
は十分な水質分析のデータを得て䨌食つ状况々照合するこ とにより確認されるるのと思われる。

Fig.1によれば，pHの 8 より 7 への变化浊腐食量を 1 枌增大させることになる。一般清浄な海水の $\mathrm{pH}$ は 8.1 前後の値を示するのを常とするが，污染海水の $\mathrm{pH}$ は 7.0 前後传まで低下していることも稀でない。したがつて，污 染海水の $\mathrm{pH}$ が清净海水の $\mathrm{pH}$ 上り低いことは腐食促進因 子として重要な㗢きをなしているるのと考兄られ，無視し らるるのではない。

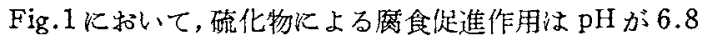
～8.0 の範囲にある時に顕著で， $\mathrm{pH}$ が 8.5 以上の時は軽 微なるのであることがわかつた：このことから，污染海水 によるアルミニウム黄銅復水器管の腐食を抑制するための 一手段として $\mathrm{pH}$ を界させる方法が考学られるので，つ ぎのような実験をおこなつて及た。すなわち，正と同様に 2 台の回転式腐食試験機汇試験片をとりつけ，その槽内に 名古屋市堀川運河の河口の污染河海水を $2 \mathrm{~L} / \mathrm{min}$ で注入 し，うち一つの槽内にの反濃厚 $\mathrm{NaOH}$ 水溶液を滴下して $\mathrm{pH}$ がつね视 8.5 前後を示すようにした。なお，堀川運河 の河海水怯，その期間 $\mathrm{pH}$ が 7.0 7.4であり，イオウイオ ンも検出されて呿り極めて污染度の大きいものであつた。 360 時間の試験後，二つの槽に捈ける試験片はそれぞれ Photo.5 のようであり， pH調節しなかった河海水に上 つて腐食された試験片には典型的な污染河海水に上る腐食
であった：このことから，pHを上昇させることが污染海 水による腐食を抑制するものであることがわかつたが，防 食法としては，Photo. 5 にも示されているごとく，pH が 上年したことにより，崖西炃カルシウムを主とする不溶性の 沈澱が金漢面比析出付着し，この付着物が復水器管の本来 の使俞である伝熱性能を著しく阻害するものと考光られる

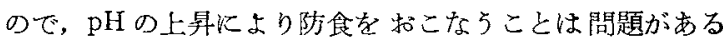
ものと思われる。

\section{VI. 総括}

污染海水によりアルミニウム黄銅復水器管の腐食に括よ ぼす要因について検討するため，硫化物(硫化水素) なたは アンモニウムイオン（塩化アンモニウム）を添加した $3 \%$ $\mathrm{NaCl}$ 溶液拈よびそ机炕 $\mathrm{pH}$ を変えた液を用いて，管を試 験片とする通水腐食試験，拉よび板を試験片とする回転式 腐食試験を行ないるざの結果を得た。

（1）徽量の硫化物は孔食を発生させ，污染海水腐食の主 因子をなしているものとみられる。

(2) アンモニウムイオンの存在は部分的な孔食を発生さ せるので，その作用も污染海水简食の一要因と考光られ る.

(3) $\mathrm{pH}$ の低下はそれ自身で腐食速度を增大させるので 污染海水腐食の一要因として重視すべきである。

(4) 硫化物次上る否食促進作用はアルカリ性 (pH 8.5 以 上）では極めて少ない，したがつて，pHを上早させるこ とによる腐食の抑制も防食法として考えられるが，難溶珄 の炭酸塩の付着があるために塞用化は困難に思わ礼る。 